\title{
Assessment on Water Quality of Waste Water in Sugar Industry and Its Impact on Environment
}

\author{
Sharmin Sultana ${ }^{*}$, Aninda Nafis Ahmed ${ }^{2}$, Shanjida Sultana ${ }^{3}$, Pradip Kumar Biswas ${ }^{3}$, \\ Badhan Saha4, Sha Alam ${ }^{3}$
}

\author{
${ }^{1}$ Institue of Glass \& Ceramic Research and Testing (IGCRT), Bangladesh Council of Scientific and Industrial Research (BCSIR), \\ Dhaka, Bangladesh \\ ${ }^{2}$ Pilot Plant and Process Development Centre (PP \& PDC), Bangladesh Council of Scientific and Industrial Research (BCSIR), \\ Dhaka, Bangladesh \\ ${ }^{3}$ Institute of Mining, Mineralogy and Metallurgy (IMMM), Bangladesh Council of Scientific and Industrial Research (BCSIR), \\ Joypurhat, Bangladesh \\ ${ }^{4}$ BCSIR Laboratories Dhaka, Bangladesh Council of Scientific and Industrial Research (BCSIR), Dhaka, Bangladesh \\ Email: *sharminkanak@yahoo.com
}

How to cite this paper: Sultana, S., Ahmed, A.N., Sultana, S., Biswas, P.K., Saha, B. and Alam, S. (2017) Assessment on Water Quality of Waste Water in Sugar Industry and Its Impact on Environment. Open Access Library Journal, 4: e3455. https://doi.org/10.4236/oalib.1103455

Received: February 13, 2017

Accepted: March 6, 2017

Published: March 9, 2017

Copyright $\odot 2017$ by authors and Open Access Library Inc.

This work is licensed under the Creative Commons Attribution International License (CC BY 4.0).

http://creativecommons.org/licenses/by/4.0/

\begin{abstract}
This present study was conducted to determine the physico-chemical properties of sugarmill waste water. Samples were collected from Joypurhat sugarmill area. Different parameters such as $\mathrm{pH}, \mathrm{EC}$, TDS, DO, BOD, COD and $\mathrm{Na}^{+}, \mathrm{K}^{+}, \mathrm{Ca}^{2+}, \mathrm{Mg}^{2+}, \mathrm{Cl}^{-}, \mathrm{SO}_{4}^{2-}, \mathrm{HCO}_{3}^{-}$etc. of these water samples were analyzed. There was a wide variation in waste water quality of before production and after production of sugarmill. This discharged waste water did not maintain standard values of inland surface water quality (according to Department of Environment, Bangladesh). Waste water from different sugarmills was also studied here. The waste water of Karu \& Kong was better than other six sugarmills. This study was done to measure quality of sugarmill waste water and to know the effect of it on surrounding environment.
\end{abstract}

\section{Subject Areas}

Hydrology

\section{Keywords}

Sugarmill, Waste Water, BOD, COD, DO, EC, ECR'97

\section{Introduction}

Sugar industries rank the second among the agro-based industries in Bangladesh. Sugar industry is seasonal in nature and operates only for 120 to 200 days in a year. The effluents released produce a high degree of organic pollution in 
both aquatic and terrestrial ecosystems. They alter the physico-chemical characteristics of receiving aquatic bodies and affect aquatic flora \& fauna [1]. Waste water from sugarmills with its high Biological Oxygen Demand (BOD) and Chemical Oxygen Demand (COD) rapidly depletes available oxygen supply when discharged into water bodies endangering fish's and other aquatic's life and also creates septic conditions, generating foul-smelling hydrogen sulfide, which in turn can precipitate iron and any dissolved salts, turning the water into black and highly toxic for aquatic life. Suspended solids reduce light penetration capability and as a result, plant production in the receiving water body is diminishing through increasing turbidity that also clogs fish gills. Discharge of water with a high Total Dissolved Solids (TDS) level would have an adverse impact on aquatic life, render the receiving water unfit for drinking and domestic purposes, reduce crop yields if used for irrigation, and exacerbate corrosion in water systems and pipe [2].

Every industry in our country should maintain the Environment Conservation rules of Bangladesh (ECR, 1997) [3]. Firstly we have to know the waste water quality of this sugarmill. After characterization we can compare it with the discharge water quality parameter of ECR'97. Then decision can be made about whether this water discharges into the water sources or not. After this irrigation suitability of it can be investigated. The main objectives of this study include the following points:

- Characterization of Joypurhat sugarmill waste water (JSW) and to compare with the irrigation water of Bangladesh.

- Comparative study on different sugarmill waste water.

- Effect of sugarmill waste water on environment.

\section{Method \& Materials}

\subsection{Study Area}

This study was done in area of Joypurhat sugarmill Ltd. which is situated at Joypurhat sador, in Joypurhat district at the time of 2014-2015. Location map of sampling site (Joypurhat sugarmill and different sugarmills) is shown in Figure 1.

\subsection{Sample Collection}

Samples were collected in two turns. First, sampling was done before starting production activity of mill in the month of December, 2014. Second, sampling was done after production activity of mill become finished in the month of February, 2015. To get the actual condition of waste water mixture, two samples were collected from each station like light $\&$ heavy. Samples were numbered as St-1, St-2, St-3 \& St-4 and nearby three pond's samples were numbered as P-1, P-2, P-3. Samples were collected along the flow path of the effluent i.e., the drain. Here pond-1 is directly connected to the discharge path of sugarmill. One sample from Tulshi-gonga river (about $30 \mathrm{~km}$ north west away from JSW) as R-1 was collected. A locally used irrigation water (shallow pump) was also collected as a control sample which will be considered as background value. $500 \mathrm{ml} \mathrm{PVC}$ 


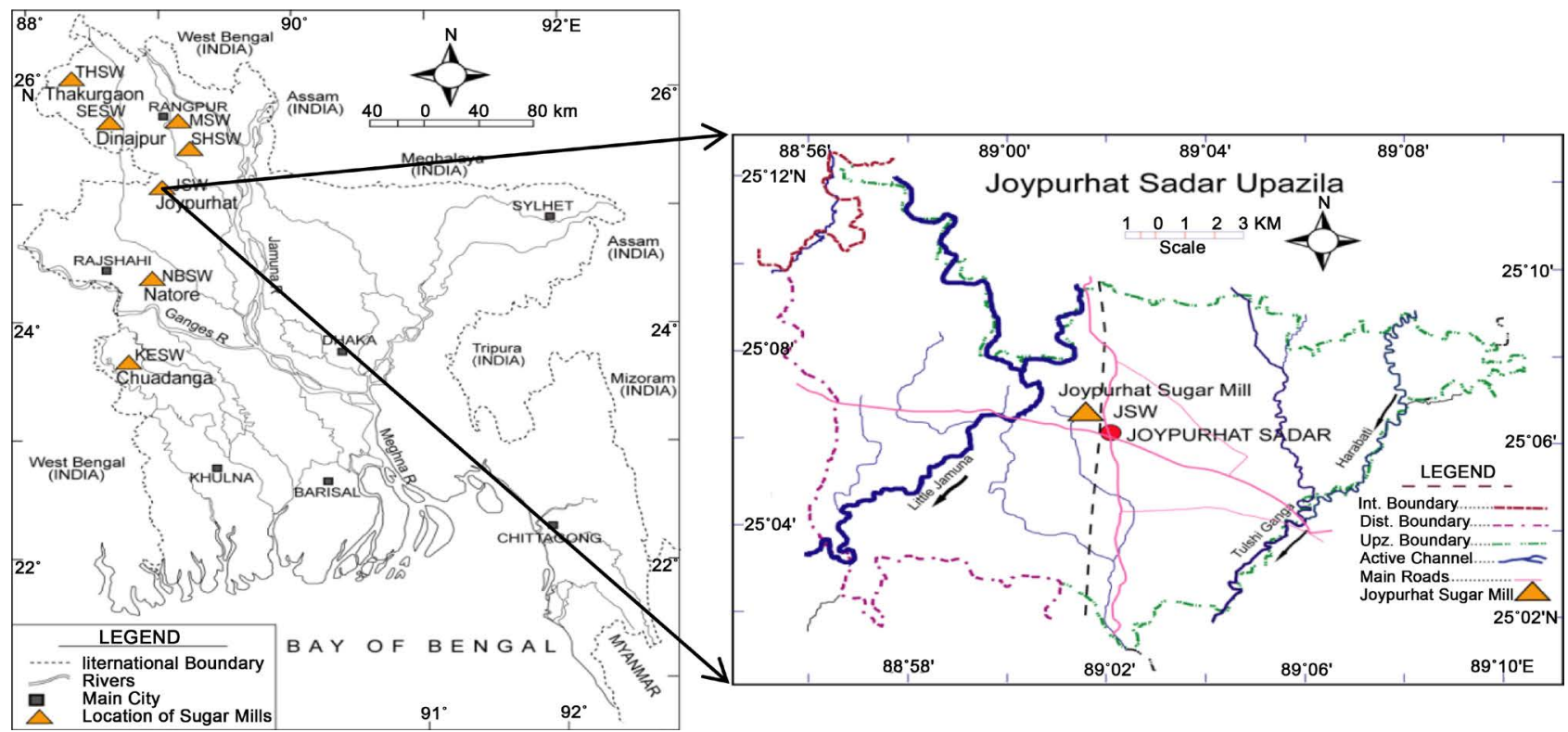

Figure 1. Location map of sampling site (different sugarmills and joypurhat sugarmill).

bottles were used for sample collection. Waste water from six sugarmills was collected at the time of after production. Seven sugarmills studied in this project were situated in north-western part of Bangladesh.

\subsection{Sample Analysis}

The physical parameters ( $\mathrm{pH}, \mathrm{EC}, \mathrm{TDS}$, Turbidity, temperature) of collected water samples were measured in Institute of Mining, Mineralogy and Metallurgy (IMMM) laboratory. Temperature was measured immediately at the sampling site by a mercury thermometer of 0 to $50^{\circ} \mathrm{C}$ range and with $0.2^{\circ} \mathrm{C}$ least count [4]. $\mathrm{pH}$ was measured by using digital $\mathrm{pH}$ meter (model: HANNA HI 96107). Electrical conductivity was measured by EC meter (model: HANNA HI- 2315). Total Dissolved Solids was measured by TDS meter (model: HANNA HI- 2300). Turbidity was measured by using turbidity meter (model: HANNA HI 93703). Raw water samples were used for physical analysis and physico-chemical analysis. Temperature and $\mathrm{pH}$ of sample was measured in the field.

The physico-chemical parameters such as DO, COD, BOD were measured by using related meters. BOD measurement was done in Dhaka laboratory, BCSIR using BOD Track Apparatus, HACH, USA. Fresh samples were used for DO and also for COD \& BOD measurement. Dissolved Oxygen was measured by digital DO meter (model: DO 5509). COD was measured by chemical titration method in IMMM laboratory. Different chemical parameters i.e., cations, anions were measured in our laboratory. The cations Sodium $\left(\mathrm{Na}^{+}\right)$, Potassium $\left(\mathrm{K}^{+}\right)$were measured by Flame photometer (model: FP 902, PG instruments). Raw samples are used for sodium \& potassium measurement. Calcium $\left(\mathrm{Ca}^{2+}\right)$ and magnesium $\left(\mathrm{Mg}^{+}\right)$were measured by titrimetric method [5]. The anions Chloride $\left(\mathrm{Cl}^{-}\right)$, Sulphate $\left(\mathrm{SO}_{4}^{2-}\right)$ and bicarbonate $\mathrm{HCO}_{3}^{-}$were done by chemical titration/ gravimetric method [6]. 


\section{Result and Discussion}

\subsection{Physico-Chemical Analysis of Joypurhat Sugarmill Waste Water}

The physico-chemical, chemical properties of Joypurhat sugarmill waste water (JSW) were determined. Physico-chemical properties of waste water at before production and after production time were presented in Table 1, Table 2 respectively.

Temperature: Temperature is basically important for its effect on certain chemical and biological radiations taking place in water for organism and inhibiting aquatic media. Salequzzaman et al. [7] studied the temperature of five different locations and observed that temperature is between $30^{\circ} \mathrm{C}$ and $40^{\circ} \mathrm{C}$. In this experiment average temperature after production time is in the range of $23^{\circ} \mathrm{C}$ to $25^{\circ} \mathrm{C}$. Here in open drain the temperature of waste water decreases with increase of time and distance.

$\mathrm{pH}: \mathrm{pH}$ is the most important parameter of water for aquatic life and microbial activity. Before starting the mill the $\mathrm{pH}$ at the discharge point ranges 7.4 to 7.7 and after starting the mill the $\mathrm{pH}$ ranges 4.0 to 6.1. It was seen that after production time, $\mathrm{pH}$ of effluent water did not maintain the standard (6-9). Here

Table 1. Results of physico-chemical analysis of sugarmill waste water at before production time.

\begin{tabular}{ccccccccc}
\hline & $\begin{array}{c}\text { Temp } \\
\left({ }^{\circ} \mathrm{C}\right)\end{array}$ & $\mathrm{pH}$ & $\begin{array}{c}\text { EC } \\
(\mu / \mathrm{cm})\end{array}$ & $\begin{array}{c}\text { TDS } \\
\mathrm{ppm}\end{array}$ & $\begin{array}{c}\text { DO } \\
(\mathrm{mg} / \mathrm{l})\end{array}$ & $\begin{array}{c}\text { BOD } \\
\mathrm{mg} / \mathrm{l}\end{array}$ & $\begin{array}{c}\text { COD } \\
\mathrm{mg} / \mathrm{l}\end{array}$ & $\begin{array}{c}\text { Turbidity } \\
(\mathrm{FTU})\end{array}$ \\
\hline St-1 & 24.1 & 7.7 & 498 & 236 & 5.1 & 22 & 412.78 & 930.2 \\
St-2 & 24.5 & 7.5 & 469 & 222 & 7.9 & 27 & 385.42 & 651.1 \\
St-3 & 25.1 & 7.4 & 689 & 326 & 9.1 & 45 & 370.79 & 454.5 \\
St-4 & 25.0 & 7.5 & 745 & 345 & 8.6 & 6.45 & 355.08 & 103.3 \\
P-1 & 24.5 & 7.5 & 474 & 223 & 8.2 & 28 & 460.89 & 60.0 \\
P-2 & 23.2 & 7.4 & 407 & 192 & 9.1 & 41 & 454.53 & 409.0 \\
P-3 & 23.0 & 7.4 & 375 & 178 & 9.0 & 20 & 282.42 & 771.1 \\
R-1 & 24.0 & 7.8 & 172 & 85 & 5.4 & 8.1 & 124.26 & 20.91 \\
\hline
\end{tabular}

Table 2. Results of physico-chemical analysis of sugarmill waste water at after production time.

\begin{tabular}{cccccccccc}
\hline $\begin{array}{c}\text { Sample } \\
\text { ID }\end{array}$ & $\begin{array}{c}\text { Temp } \\
\left({ }^{\circ} \mathrm{C}\right)\end{array}$ & $\mathrm{pH}$ & $\begin{array}{c}\text { EC } \\
(\mu / \mathrm{cm})\end{array}$ & $\begin{array}{c}\text { TDS } \\
\mathrm{ppm}\end{array}$ & $\begin{array}{c}\text { DO } \\
(\mathrm{mg} / \mathrm{l})\end{array}$ & $\begin{array}{c}\text { BOD } \\
\mathrm{mg} / \mathrm{l}\end{array}$ & $\begin{array}{c}\text { COD } \\
\mathrm{mg} / \mathrm{l}\end{array}$ & $\begin{array}{c}\text { Turbidity } \\
(\mathrm{FTU})\end{array}$ & Colour \\
\hline St-1 & 23.9 & 4.0 & 4675 & 2572 & 2.6 & 69 & 673 & 863 & deep yellowish \\
St-2 & 24.0 & 4.4 & 2190 & 1205 & 2.1 & 55 & 506 & 589 & dark brown \\
St-3 & 24.0 & 4.8 & 2245 & 1235 & 0.3 & 128 & 521 & $>1000$ & brown to black \\
St-4 & 24.0 & 5.0 & 2450 & 1348 & 0.4 & 105 & 519 & $>1000$ & Blackish \\
P-1 & 24.0 & 6.1 & 3090 & 1699 & 2.8 & 98 & 612 & $>1000$ & Yellowish \\
P-2 & 24.0 & 8.3 & 573 & 315 & 4.4 & 18 & 109 & 40.81 & Colourless \\
P-3 & 24.1 & 7.3 & 570 & 314 & 6.6 & 20 & 114 & 0.00 & light greenish \\
R-1 & 24.2 & 7.1 & 365 & 245 & 6.2 & 8.9 & 68 & 5.6 & Turbid \\
Control & 24.1 & 6.9 & 193.4 & 106.37 & 4.7 & 8.3 & 48 & 2.1 & Colorless \\
\hline
\end{tabular}


$\mathrm{pH}$ of control sample was 7.2.

Electrical conductivity: The EC of water is an indicator of salinity and hazard that gives the total salt concentration in water (Brady and Well, 2002) [8]. There is a tremendous increase in concentration of EC during production time. Before production the EC ranges $474-745 \mu \mathrm{s} / \mathrm{cm}$ and after production the EC ranges $2190-3090 \mu \mathrm{s} / \mathrm{cm}$. According to DoE the EC of effluent should be below $1200 \mu / \mathrm{cm}$. After production the discharge water at all stations did not maintain the standard, the values are above the standard. Four stations have higher EC than river and pond water. But pond-1 is different from other two ponds because this pond is directly connected to mill drain.

Turbidity: Turbidity ranges from 109 - 930 FTU at before production time. After production time turbidity was found over 1000 FTU. Too much turbid water is not suitable for aquatic flora and fauna because sunlight cannot pass through the turbid water.

Total Dissolved Solid: TDS also increase tremendously after production. Before starting TDS of effluent ranges 222 to $345 \mathrm{ppm}$ and after production TDS ranges 1205 to $1699 \mathrm{ppm}$. According to DoE values of after production time are below the inland surface water standard (2100 ppm). TDS value of control sample (106 ppm) was lower than JSW.

Dissolved Oxygen: According to DoE standard, effluent should be within the range of 4.5 to $8 \mathrm{mg} / \mathrm{l}$. After production time $\mathrm{DO}$ is almost absent that means at all stations the DO values are $<1$, only st- 1 contains $2.6 \mathrm{mg} / \mathrm{l}$. Before production time DO was good (range $5.1-9.1 \mathrm{mg} / \mathrm{l}$ ). Control sample of that area has DO value $4.7 \mathrm{mg} / \mathrm{l}$.

Biological Oxygen Demand: One of the most important parameter for aquatic life is BOD. After production time BOD ranges from 55 to $128 \mathrm{mg} / \mathrm{l}$, which was 22 - $45 \mathrm{mg} / \mathrm{l}$ in before production time. Control sample of that area has BOD $8.3 \mathrm{mg} / \mathrm{l}$. JSW should be $<50 \mathrm{mg} / \mathrm{l}$ to discharge into the water body.

Chemical Oxygen Demand: It is another important parameter for aquatic life. During production time, this water contains higher COD values ranges from 506 to $673 \mathrm{mg} / \mathrm{l}$. COD values decreases with the distance of flow path and st-1 contains highest COD values $(673 \mathrm{mg} / \mathrm{l})$. COD values of four stations were much higher than the control value $(48 \mathrm{mg} / \mathrm{l})$.

\subsection{Chemical Analysis of Joypurhat Sugarmill Waste Water}

The chemical properties (cations \& anions) of waste water at before and after production time were presented in Table 3, Table 4.

\subsubsection{Analysis of Cations}

Sodium: There is a tremendous change in concentration of sodium at the time of before (16 - $38 \mathrm{ppm})$ and after production time (352 - $890 \mathrm{ppm})$. According to surface water standard the $\mathrm{Na}^{+}$in fresh water should be $6.3 \mathrm{ppm}$ [9]. After production, sodium concentration was higher than the background or control value (14.8).

Potassium: According to Garrels and Mackenzie the surface water standard 
Table 3. Analysis of cations of sugarmill waste water.

\begin{tabular}{ccccccccc}
\hline \multicolumn{3}{c}{ Before production } & \multicolumn{5}{c}{ After production } \\
\hline $\begin{array}{c}\text { Sample } \\
\text { ID }\end{array}$ & $\begin{array}{c}\mathrm{Na}^{2+} \\
\mathrm{ppm}\end{array}$ & $\begin{array}{c}\mathrm{K}^{+} \\
\mathrm{ppm}\end{array}$ & $\begin{array}{c}\mathrm{Ca}^{2+} \\
\mathrm{ppm}\end{array}$ & $\begin{array}{c}\mathrm{Mg}^{2+} \\
\mathrm{ppm}\end{array}$ & $\begin{array}{c}\mathrm{Na}^{+} \\
\mathrm{ppm}\end{array}$ & $\begin{array}{c}\mathrm{K}^{+} \\
\mathrm{ppm}\end{array}$ & $\begin{array}{c}\mathrm{Ca}^{2+} \\
\mathrm{ppm}\end{array}$ & $\begin{array}{c}\mathrm{Mg}^{2+} \\
\mathrm{ppm}\end{array}$ \\
\hline St-1 & 17.5 & 18.5 & $\mathrm{BDL}$ & $\mathrm{BDL}$ & 475 & 242 & 460 & 141.6 \\
St-2 & 16 & 12 & $\mathrm{BDL}$ & $\mathrm{BDL}$ & 352 & 206 & 400 & 206.4 \\
St-3 & 18 & 17 & $\mathrm{BDL}$ & $\mathrm{BDL}$ & 890 & 210 & 188 & 93.6 \\
St-4 & 38 & 20 & $\mathrm{BDL}$ & $\mathrm{BDL}$ & 508 & 212 & 240 & 7.2 \\
P-1 & 25 & 14 & $\mathrm{BDL}$ & $\mathrm{BDL}$ & 653 & 167 & 200 & 0.00 \\
P-2 & 19 & 24 & $\mathrm{BDL}$ & $\mathrm{BDL}$ & 37 & 26 & 186 & 0.00 \\
P-3 & 26 & 20 & $\mathrm{BDL}$ & $\mathrm{BDL}$ & 43 & 24 & 160 & 0.00 \\
$\mathrm{R}-1$ & 15 & 23 & $\mathrm{BDL}$ & $\mathrm{BDL}$ & 25 & 63 & 100 & 26.4 \\
& & Control & & & 14.8 & 7.1 & 14.5 & 13.2 \\
\hline
\end{tabular}

${ }^{\star} \mathrm{BDL}=$ Below detection limit.

Table 4. Analysis of anions of sugarmill waste water.

\begin{tabular}{ccccccc}
\hline & \multicolumn{3}{c}{ Before production } & \multicolumn{3}{c}{ After production } \\
\hline Sample ID & $\begin{array}{c}\mathrm{SO}_{4}^{2-} \\
\mathrm{ppm}\end{array}$ & $\begin{array}{c}\mathrm{Cl}{ }^{-} \\
\mathrm{ppm}\end{array}$ & $\begin{array}{c}\mathrm{HCO}_{3}^{-} \\
\mathrm{ppm}\end{array}$ & $\begin{array}{c}\mathrm{SO}_{4}^{2-} \\
\mathrm{ppm}\end{array}$ & $\begin{array}{c}\mathrm{Cl}^{-} \\
\mathrm{ppm}\end{array}$ & $\begin{array}{c}\mathrm{HCO}_{3}^{-} \\
\mathrm{ppm}\end{array}$ \\
\hline St-1 & 1.33 & 22.15 & 175.3 & 5.5 & 3500.69 & $\mathrm{BDL}$ \\
St-2 & 0.44 & 15.51 & 198.25 & 2.0 & 700.14 & $\mathrm{BDL}$ \\
St-3 & 0.51 & 64.25 & 259.25 & 1.63 & 443.12 & $\mathrm{BDL}$ \\
St-4 & 0.18 & 70.90 & 207.4 & 1.88 & 664.69 & $\mathrm{BDL}$ \\
P-1 & 0.58 & 22.16 & 221.1 & 1.40 & 797.63 & $\mathrm{BDL}$ \\
P-2 & 0.00 & 44.31 & 230.2 & 0.00 & 221.56 & $\mathrm{BDL}$ \\
P-3 & 0.00 & 60.90 & & 0.00 & 230.02 & $\mathrm{BDL}$ \\
R-1 & 0.00 & & 0.00 & 0.00 & 35.45 & $\mathrm{BDL}$ \\
Control & & & & & 44.32 & 41.18 \\
\hline
\end{tabular}

the $\mathrm{K}^{+}$in fresh water should be $2.3 \mathrm{ppm}$ [9]. The same condition was found for potassium. It ranges from 12 to $20 \mathrm{ppm}$ at before production and $167-242 \mathrm{ppm}$ at after production time. Potassium content of after production is much higher than the control value $(7.1 \mathrm{ppm})$. Higher concentration of sodium and potassium are not harmful because these two cations will increase fertility status of agricultural soil.

Calcium: According to surface water standard the $\mathrm{Ca}^{2+}$ in fresh water should be $15 \mathrm{ppm}$ [9]. In this experiment, calcium concentration could not be determined by gravimetric method. But after production time it was found in range of $240-460 \mathrm{ppm}$. Background or control value of that area was $14.5 \mathrm{ppm}$.

Magnesium: According to surface water standard the $\mathrm{Mg}^{2+}$ in fresh water should be $4.1 \mathrm{ppm}$ [9]. $\mathrm{Mg}^{2+}$ concentration could not be determined in before production time by gravimetric method. After production time wide variation 
(7.2 - $141.6 \mathrm{ppm}$ ) was found in four stations. It was also found that ponds and river water was changed during production time. Control value of that area was $13.2 \mathrm{ppm}$.

\subsubsection{Analysis of Anions}

Chlorides: According to surface water standard the $\mathrm{Cl}^{-}$in fresh water should be 7.8 ppm (Garrels and Mackenzie, 1971) [9]. Before production $\mathrm{Cl}^{-}$ranges 22.1 $70.90 \mathrm{ppm}$ and after production time it ranges from 664.69 to $350.690 \mathrm{ppm}$. $\mathrm{Cl}^{-}$ concentration was much higher than the Control value (44.31 ppm).

Sulphates: According to surface water standard the $\mathrm{SO}_{4}^{-}$in fresh water should be 11.2 ppm (Garrels and Mackenzie, 1971) [9] Sulphate concentrations in after production time ranges 1.88 to 5.5. $\mathrm{SO}_{4}^{-}$ppm conc. of control sample was nill.

Bicarbonates: Before production time conc. of bicarbonate was in range of 175.3 to $259.25 \mathrm{ppm}$. After production time $\mathrm{HCO}_{3}^{-}$could not be detected by gravimetric method. According to surface water standard $\mathrm{HCO}_{3}^{-}$in fresh water should be 58.4 ppm (Garrels and Mackenzie, 1971) [9]. Average value (217.25 ppm) of after production time was much higher than the control value (41.18 ppm).

\subsection{Variation of Different Parameters with Stations}

Samples were collected from different stations such as along discharge path (st-1, 2, $3 \& 4)$ and three from ponds (beside drain) and one from river (30 km away from discharge path). A wide variation was found in different parameters of JSW with stations. Graphical presentation of some important parameters of JSW is shown in Figure 2. Pond-1 was different than other two ponds because it was situated between st-1 \& st-2 and directly connected to sugarmill drain.

\subsection{Comparison of Joypurhat Sugarmill Waste Water with Different Standards of Water}

The water quality parameters of JSW were compared with DoE (Department of Environment) standard and inland surface water standard and comparison is shown in Table 5. The BOD and EC results are shown in Figure 3 where comparison of samples from different stations is made with standards. ECR'97 was followed here but this guide had no COD standard value for inland surface and irrigation water. So, COD value could not be shown in this table and JSW value was compared with local irrigation water only. Average temperature of JSW $\left(23.5^{\circ} \mathrm{C}\right)$ was between the range of inland surface and irrigation water. In this case temperature is not a problem because it depends on the thermal condition of environment. The main problem is very low or negligible dissolved oxygen (DO) value of waste water. Lower pH of JSW is also a problem. TDS value of JSW was lower than inland surface water value. Though TDS was lower the JSW could not be discharged into open environment because of very low DO, lower $\mathrm{pH}$ and higher BOD.

\subsection{Comparative Study on Different Sugarmills Waste Water}

Physico-chemical properties of seven sugarmills waste water were presented in 
Table 6. These seven sugarmills were located in the north-western part of Bangladesh. The waste water quality of sugarmill depends on some issues such as operation procedure of mill, maintenance of machines, open or covered drainage system, underground drainage system etc.

Each sugarmill studied in this project has waste water of very low $\mathrm{pH}$ or acidic in nature. Considering BOD it was seen that SESW $>$ SHSW $>$ NBSW $>$ MSW $>$ KASW > THSW > JSW. Among seven, waste water of Shetabgonj sugarmill was
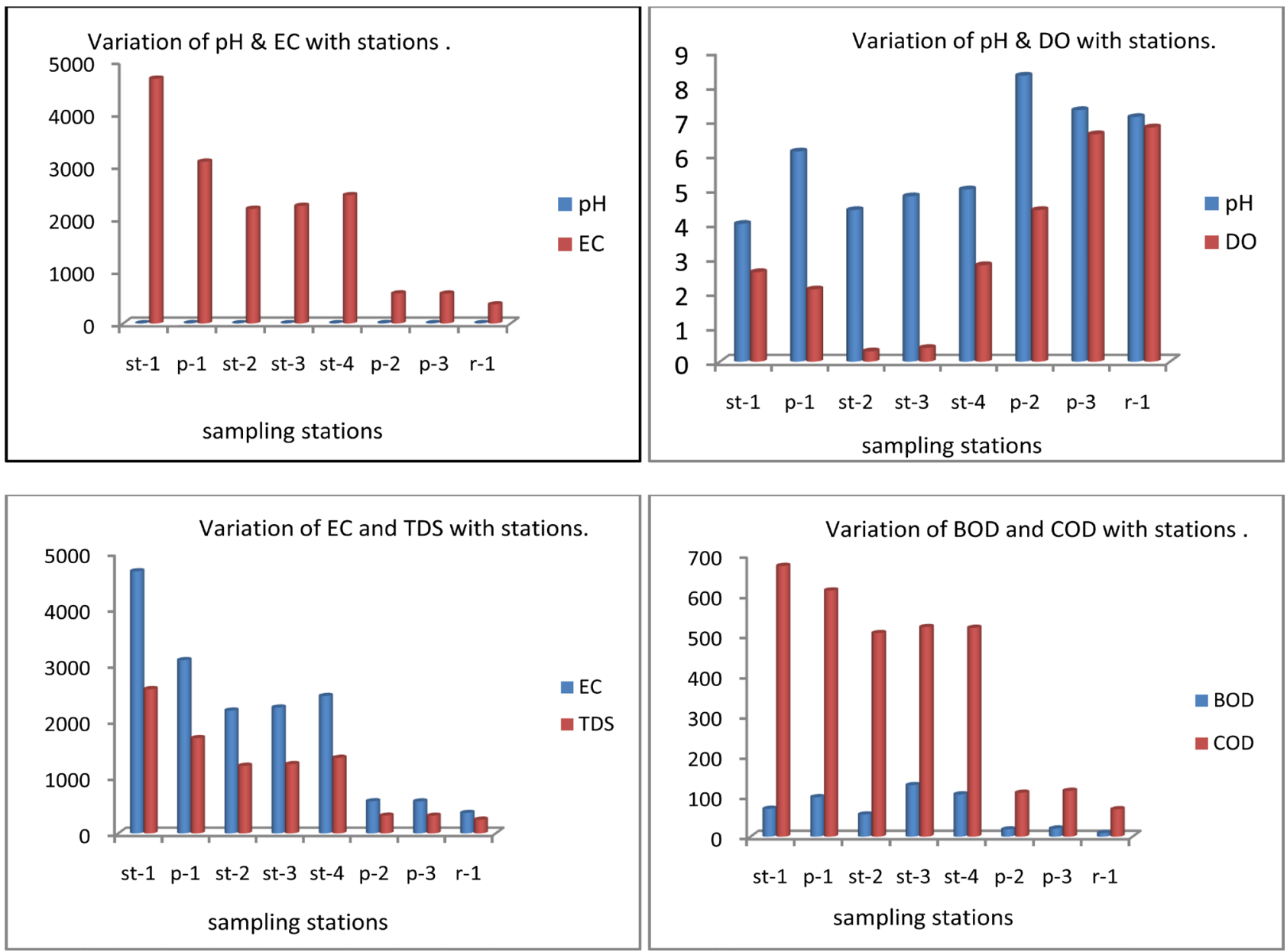

Figure 2. Variation on some parameters of JSW with stations.

Table 5. Comparision of Joypurhat sugarmill waste water with standard values of inland surface water and irrigation water.

\begin{tabular}{ccccc}
\hline Parameter & JSW water (after production) & Inland surface water & Irrigation water & Local irrigation water (control) \\
\hline Temp $\left({ }^{\circ} \mathrm{C}\right)$ & $23-24$ & 40 & $20-30$ & 24.1 \\
$\mathrm{pH}$ & $4.0-6.1$ & $6.0-9.0$ & $6.5-8.5$ & 7.2 \\
$\mathrm{DO}(\mathrm{mg} / \mathrm{l})$ & $0.3-2.8$ & $4.5-8.0$ & 5 or more & 4.7 \\
$\mathrm{EC}(\mu / \mathrm{cm})$ & $2190-3090$ & 1200 & $700-3000$ & 193.6 \\
$\mathrm{TDS}(\mathrm{mg} / \mathrm{l})$ & $1205-1699$ & 2100 & $450-2000$ & 106 \\
$\mathrm{BOD}$ & $55-128$ & 50 (sugar industry to discharge) & 10 or less & 8.3 \\
$\mathrm{COD}$ & $506-673$ & & & 48 \\
\hline
\end{tabular}

(Source: ECR Act 1995 and Rules 1997). 

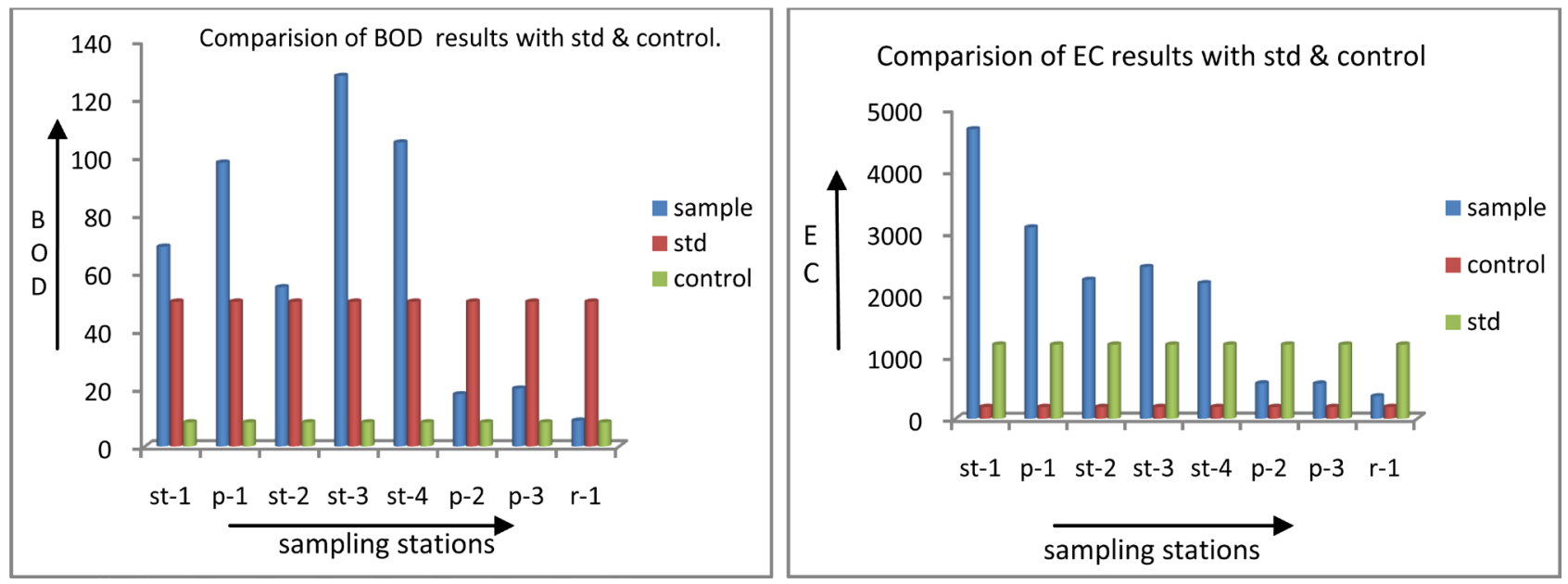

Figure 3. Comparison of JSW with standard and control values.

Table 6. Results of different sugarmills waste water (after production).

\begin{tabular}{|c|c|c|c|c|c|c|}
\hline Sample id & $\mathrm{pH}$ & $\mathrm{EC} \mu \mathrm{s} / \mathrm{cm}$ & TDS ppm & DO mg/l & BOD mg/l & COD mg/l \\
\hline JSW & 4.6 & 2890 & 1590 & 0.3 & 89.25 & 554.75 \\
\hline NBSW & 6.7 & 1072 & 536 & 0.00 & 125 & 598 \\
\hline MSW & 6.6 & 440 & 220 & 0.00 & 114 & 560 \\
\hline SHSW & 4.4 & 387 & 193 & 0.00 & 128 & 498 \\
\hline SESW & 4.3 & 1792 & 896 & 0.00 & 139 & 603 \\
\hline THSW & 4.3 & 3420 & 1710 & 0.00 & 102 & 661 \\
\hline KASW & 3.9 & 518 & 259 & 0.00 & 104 & 98 \\
\hline
\end{tabular}

JSW = Joypurhat sugarmill waste water, NBSW $=$ North Bangle sugarmill waste water, MSW = Mahimagonj sugarmill waste water, SHSW $=$ Shampur sugarmill waste water, SESW = Setabgonj sugarmill waste water, THSW = Thakurgon sugarmill waste water, KASW = Karu \& Kong sugarmill waste water.

worser than any other sugarmill in with tremendous odor. DO value of seven sugarmills are nill which is alarming for aquatic life. In case of EC it was found that $\mathrm{THSW}>$ JSW $>$ SESW $>$ NBSW $>$ KASW $>$ MSW $>$ SHSW. The waste water of MSW and KASW sugarmills were better than others because these two sugarmill have treatment plant. Six sugarmills of Table 6 have COD over 400 mg/l except KASW (98 mg/l). The waste water of Karu \& Kong sugarmill was better than others.

\subsection{Effect of Joypurhat Sugarmill Waste Water on Environment}

Though sugarmill performs only 4 - 6 months, it does harm to surrounding environment. During production time, waste water discharges from Joypurhat sugarmill at a rate of 30.28 cubic meters per hour [10]. After closing sugarmill, colour of drain water becomes black. Nearby two ponds which were not directly connected to sugarmill drain that were also changed after production of sugarmill. Excess BOD, COD, low $\mathrm{pH}$ and negligible DO value of waste water causes harm to connected river. When the production of joypurhat sugarmill becomes finished then Tulshi Gonga river water turns into black colour. As a result that river (Tulshi Gonga) water becomes unsuitable for aquatic life. Rural people who 
use this water for their household work are suffering from skin diseases. People of that area are disturbed by strong fouling odour of sugarmill waste water.

\section{Conclusions}

1. Due to high BOD, COD, low $\mathrm{pH}$ and zero level of DO, Joypurhat sugarmill waste water is not suitable for irrigational use. The waste water quality of this sugarmill is harmful for aquatic life. A suitable treatment method should be developed for this sugarmill.

2. If it is treated, it can be an essential source of irrigation water. Because Joypurhat sugarmill waste water is rich in sodium, potassium, calcium, magnesium which can increase fertility status of soil.

3. Studying on different sugarmill waste water (considering BOD), the order was found as follows: SESW $>$ SHSW $>$ NBSW $>$ MSW $>$ KASW $>$ THSW $>$ JSW. The waste water of Mahimagonj sugarmill and Karu \& Kong sugarmill was found better than other sugarmills because they have treatment plant. So, every sugarmill should have treatment plant.

\section{Acknowledgements}

We would like to thank Bangladesh Council of Scientific and Industrial Research (BCSIR) authority for giving financial support for this $\mathrm{R} \& \mathrm{D}$ (research and development) project. We also want to thank Director Dr. Nazim Zaman, Institute of Mining, Mineralogy and Metallurgy (IMMM), BCSIR, Joypurhat for his cooperation and inspiration. We are also grateful to the scientists, technicians and lab attendants for their support to complete this project.

\section{References}

[1] Baruah, A.K., Sharma, R.N. and Borah, G.C. (1993) Impact of Sugarmill and Distillery Effluents on Water Quality of River Gelabil Assam. Indian Journal of Environmental Health, 35, 288-293.

[2] Brady, N.C. and Well, R.R. (2002) The Nature and Properties of Soils. 12th Edition, Pearson Education Inc., New Delhi, 42-43.

[3] Baskaran, L., Sundaramoorthy, P., Chimbaram, A.L.A. and Ganesh, K.S. (2009) Growth and Physiological Activity of Greengram (Vigna radiata L.) under Effluent Stress. BioMed Research International, 2, 107-114.

[4] Doe (1997) Department of Environment, Bangladesh Gazette, No. Da-1; Ministry of Environment and Forest. 1324-1327.

[5] ETPI (2001) Environmental Technology Program for Industry "Environmental Report on Sugar Sector". Monthly Environmental News, 5, 11-27.

[6] Garrels, R.M. and Mackenzie, R.T. (1971) Evolution of Sedimentary Rocks. New York.

[7] Guide Manual: Water and Waste Water Analysis, Authored by: Central Pollution Control Board (CPCB). 60-63.

[8] Gupta, P.K. (2000) Methods in Environmental Analysis: Water, Soil and Air. Agrobois, Jodhpur, India, 5-76.

[9] Salequzzaman, M., Tariqul Islam, S.M., Tasnuva, A., Kashem, M.A. and Mahedial 
Masud, M. (2008) Environment Impact of Sugar Industry: A Case Study on Kushtia Sugar Mills. Bangladesh Journal of Innovation and Development Strategy, 2, 31-35.

[10] Annual Report of Sugarcane Crushing Season of Joypurhat Sugarmill Ltd.: 20142015.

Submit or recommend next manuscript to OALib Journal and we will provide best service for you:

- Publication frequency: Monthly

- 9 subject areas of science, technology and medicine

- Fair and rigorous peer-review system

- Fast publication process

- Article promotion in various social networking sites (LinkedIn, Facebook, Twitter, etc.)

- Maximum dissemination of your research work

Submit Your Paper Online: Click Here to Submit

Or Contact service@oalib.com 